\title{
Unexpected rise of ozone in urban and rural areas, and sulfur dioxide in rural areas during the coronavirus city lockdown in Hangzhou, China: implications for air quality
}

\author{
Liqiang Wang ${ }^{1} \cdot$ Mengying $\mathrm{Li}^{1} \cdot$ Shaocai $\mathrm{Yu}^{1,2}{ }^{10} \cdot \mathrm{Xue}^{\mathrm{Chen}}{ }^{1} \cdot \mathrm{Zhen}_{\mathrm{Li}}{ }^{1} \cdot$ Yibo Zhang ${ }^{1} \cdot$ Linhui Jiang $^{1} \cdot$ Yan Xia ${ }^{1}$. \\ Jiali $\mathrm{Li}^{1} \cdot$ Weiping Liu ${ }^{1} \cdot$ Pengfei $\mathrm{Li}^{3} \cdot$ Eric Lichtfouse $^{4,5}$ - Daniel Rosenfeld ${ }^{6} \cdot$ John H. Seinfeld ${ }^{2}$
}

Received: 13 May 2020 / Accepted: 1 June 2020 / Published online: 12 June 2020

(c) Springer Nature Switzerland AG 2020

\begin{abstract}
The outbreak of coronavirus named COVID-19, initially identified in Wuhan, China in December 2019, has spread rapidly at the global scale. Most countries have rapidly stopped almost all activities including industry, services and transportation of goods and people, thus decreasing air pollution in an unprecedented way, and providing a unique opportunity to study air pollutants. While satellite data have provided visual evidence for the global reduction in air pollution such as nitrogen dioxide $\left(\mathrm{NO}_{2}\right)$ worldwide, precise and quantitative information is missing at the local scale. Here we studied changes in particulate matter $\left(\mathrm{PM}_{2.5}, \mathrm{PM}_{10}\right)$, carbon monoxide $(\mathrm{CO}), \mathrm{NO}_{2}$, sulfur dioxide $\left(\mathrm{SO}_{2}\right)$ and ozone $\left(\mathrm{O}_{3}\right)$ at 10 urban sites in Hangzhou, a city of 7.03 million inhabitants, and at 1 rural site, before city lockdown, January 1-23, during city lockdown, January 24-February 15, and during resumption, February 16-28, in 2020. Results show that city lockdown induced a sharp decrease in $\mathrm{PM}_{2.5}, \mathrm{PM}_{10}, \mathrm{CO}$, and $\mathrm{NO}_{2}$ concentrations at both urban and rural sites. The $\mathrm{NO}_{2}$ decrease is explained by reduction in traffic emissions in the urban areas, and by lower regional transport in rural areas during lockdown, as expected. $\mathrm{SO}_{2}$ concentrations decreased from 6.3 to $5.3 \mu \mathrm{g} \mathrm{m}^{-3}$ in the city, but increased surprisingly from 4.7 to $5.8 \mu \mathrm{g} \mathrm{m}^{-3}$ at the rural site: this increase is attributed both to higher coal consumption for heating and emissions from traditional fireworks of the Spring Eve and Lantern Festivals during lockdown. Unexpectedly, $\mathrm{O}_{3}$ concentrations increased by $145 \%$ from 24.6 to $60.6 \mu \mathrm{g} \mathrm{m}^{-3}$ in the urban area, and from 42.0 to $62.9 \mu \mathrm{g} \mathrm{m}^{-3}$ in the rural area during the lockdown. This finding is explained by the weakening of chemical titration of $\mathrm{O}_{3}$ by $\mathrm{NO}$ due to reductions of $\mathrm{NO}_{\mathrm{x}}$ fresh emissions during the non-photochemical reaction period from 20:00 PM to 9:00 AM (local time). During the lockdown, compared to the same period in 2019, the daily average concentrations in the city decreased by $42.7 \%$ for $\mathrm{PM}_{2.5}, 47.9 \%$ for $\mathrm{PM}_{10}, 28.6 \%$ for $\mathrm{SO}_{2}, 22.3 \%$ for $\mathrm{CO}$ and $58.4 \%$ for $\mathrm{NO}_{2}$, which is obviously explained by the absence of city activities. Overall, we observed not only the expected reduction in some atmospheric pollutants $\left(\mathrm{PM}, \mathrm{SO}_{2}, \mathrm{CO}, \mathrm{NO}_{2}\right)$, but also unexpected increases in $\mathrm{SO}_{2}$ in the rural areas and of ozone $\left(\mathrm{O}_{3}\right)$ in both urban and rural areas, the latter being paradoxically due to the reduction in nitrogen oxide levels. In other words, the city lockdown has improved air quality by reducing $\mathrm{PM}_{2.5}, \mathrm{PM}_{10}, \mathrm{CO}$, and $\mathrm{NO}_{2}$, but has also decreased air quality by augmenting $\mathrm{O}_{3}$ and $\mathrm{SO}_{2}$.
\end{abstract}

Keywords COVID-19 $\cdot$ Hangzhou $\cdot$ Lockdown $\cdot$ Air quality $\cdot$ Emission reductions $\cdot$ Coronavirus $\cdot \mathrm{PM}_{2.5} \cdot \mathrm{PM}_{10} \cdot \mathrm{SO}_{2}$. $\mathrm{CO} \cdot \mathrm{NO}_{2} \cdot \mathrm{O}_{3}$

Liqiang Wang and Mengying Li these authors contributed equally to this work.

Electronic supplementary material The online version of this article (https://doi.org/10.1007/s10311-020-01028-3) contains supplementary material, which is available to authorized users.

Extended author information available on the last page of the article

\section{Introduction}

In early December 2019, the novel coronavirus pneumonia named COVID-19 by the World Health Organization (WHO) was initially identified in Wuhan, the capital city of Hubei province (Huang et al. 2020; Guan et al. 2020; WHO, 2019). As of May 28, 2020, COVID-19 had spread rapidly on a global scale with 5,491,678 confirmed cases, 349,190 confirmed deaths in 217 countries, areas or territories, as 
reported by the WHO (https://www.who.int/emergencie s/diseases/novel-coronavirus-2019). To curb the spread of COVID-19, Wuhan and other cities of Hubei province announced lockdowns on January 23 and 24, 2020, respectively, followed by other provinces in China, by declaring the highest level of a public health emergency on January 26, 2020 (Tian et al. 2020). As part of the national emergency response, the Chinese government established nationally strict curfews and isolation policies, named 'lockdown', for instance:

- extending the Spring Festival holiday,

- suspending all public transportation including city buses, subways, ferries and long-distance coaches,

- closing outbound channels at airports and railway stations,

- closing schools and entertainment venues,

- banning public gatherings,

- enhancing social distancing, and

- issuing stay-at-home orders and closing non-essential businesses.

Future analyses will evaluate the extent to which these approaches have been effective, and whether potential benefits have outweighed the costs, e.g., economic losses. Non-essential businesses in most areas resumed work after February 10, although non-essential businesses in Wuhan remained closed until March 20.

The all-out massive efforts of the Chinese government by sealing off all cities in a bid to curb the spread of the COVID-19 provide an unprecedented opportunity to study the possible effects of anthropogenic emission on air quality. NASA and European Space Agency (ESA) pollution monitoring satellites, i.e., the Tropospheric Monitoring Instrument (TROPOMI) on ESA's Sentinel-5 satellite, detected significant decreases in $\mathrm{NO}_{2}$ over China based on the data from January 1-20, 2020, before the quarantine, to February 10-25, during the quarantine (NASA 2020). There is evidence that the changes were at least partly related to the economic slowdown following the coronavirus outbreak. By comparison of $\mathrm{NO}_{2}$ values in 2020 with the average values detected at this time of year from 2005 to 2019, NASA determined that $\mathrm{NO}_{2}$ concentrations in eastern and central China in 2020 were $10-30 \%$ lower than those normally observed for this time period (NASA 2020).

On the other hand, despite reduction in activities at the outbreak of COVID-19, the Beijing-Tianjin-Hebei cluster remained shrouded in smog during the Spring Festival holiday in 2020 despite the expectation that air pollution would remain low (MEE 2020; China Daily 2020). On Wednesday, February 5, 2020, hourly concentrations of $\mathrm{PM}_{2.5}-$ fine particles with an aerodynamic diameter lower than $2.5 \mu \mathrm{m}$-in most districts in Beijing exceeded $200 \mu \mathrm{g} \mathrm{m}^{-3}$ with worsening haze over the Lantern Festival on Saturday, February 9 (MEE 2020). It was estimated that from January 24 to February 2, 2020, pollutant emissions, with $77 \%$ fewer freight vehicles and 39\% fewer cars on the roads, decreased by at least $40 \%$ in the 28 major cities in the Beijing-Tianjin-Hebei (BTH) cluster (MEE 2020). However, emissions from industries such as steel, nonferrous metals, glass, cooking and heating in the BTH cluster remained generally unchanged, despite a suspension of activities by many restaurants and labor-intensive factories (MEE 2020). There was a decrease of only $10 \%$ in emissions by steel plants and coal-burning power generation sectors with no decrease in other smokestack industries. About 10 million rural households in the BTH region relied on coal for heating, with some shift to cleaner energy like natural gas. Coal consumption for heating increased as reflected by more than $10 \%$ enhancement of $\mathrm{CO}$ concentrations, relative to last year in the BTH rural areas. Another major factor for poor air quality in the BTH region during the cold periods was the unfavorable meteorological conditions for pollutant dispersal, such as mixing layer heights of only 300 to $500 \mathrm{~m}$, half to one-third of their normal heights in the same season in MEE (2020).

Elevated $\mathrm{PM}_{2.5}$ is a major factor controlling regional climate and human health (van Donkelaar et al. 2010; Yu et al. 2014; Wang et al. 2014a; Rosenfeld et al. 2019; Pope 2000; Seinfeld and Pandis 2016; Chen et al. 2013). The main driver of decreases in $\mathrm{PM}_{2.5}$ in China between 2013 and 2017 was strict emission control policies (Zhang et al. 2019; Ding et al. 2019). Efforts to improve air quality during large international events, such as the 2008 Beijing Olympics, the 2014 Beijing Asia-Pacific Economic Cooperation (APEC) summit, the 2015 Grand Military Parade, and the 2016 Hangzhou G20 summit, have included short-term closure of power plants and factories, restriction of traffic, and reduction in construction activities (Xing et al. 2011; Liu et al. 2016; Li et al. 2017; Wang et al. 2017).

Hangzhou, the capital of Zhengjiang Province situated in the Yangtze River Delta and one of the most famous and prosperous cities in China (Fig. 1), has a population of 7.03 million and covers an area over 16,000 $\mathrm{km}^{2}$ (http://xzqh. mca.gov.cn/). Influenced by subtropical monsoon climate, Hangzhou has four distinctive seasons. Surrounded by mountains on three sides, this city belongs to basin geomorphology which does not favor pollution dispersal. Due to the implementation of pollution control strategies such as restructuring of industry and energy, coal consumption decreased from 14.6 million tons in 2005 to 13.4 million tons in 2013, despite doubling the numbers of vehicles from 1.1 to 2.5 million (http://www.hangzhou.gov.cn/col/col 80 5867/).

Heavy photochemical pollution and haze episodes occur frequently with exceedances in 2013 of 38 days for $\mathrm{O}_{3}$ and 
Fig. 1 a Distributions of 11 air quality monitoring station locations in Hangzhou. b Time series of observed hourly concentrations of $\mathrm{PM}_{2.5}, \mathrm{PM}_{10}$, $\mathrm{SO}_{2}, \mathrm{CO}, \mathrm{NO}_{2}, \mathrm{O}_{3}$ at urban and rural sites in Hangzhou city from January 1 to February 28, 2020. Comparing pollutant levels before lockdown and during lockdown, concentrations of $\mathrm{PM}_{2.5}, \mathrm{PM}_{10}, \mathrm{CO}, \mathrm{NO}_{2}$ displayed significantly decreases, while overall augmentations were observed for $\mathrm{O}_{3}$ in both urban and rural areas. The patterns began to reverse after February 15 due to the resumption of work and production activities
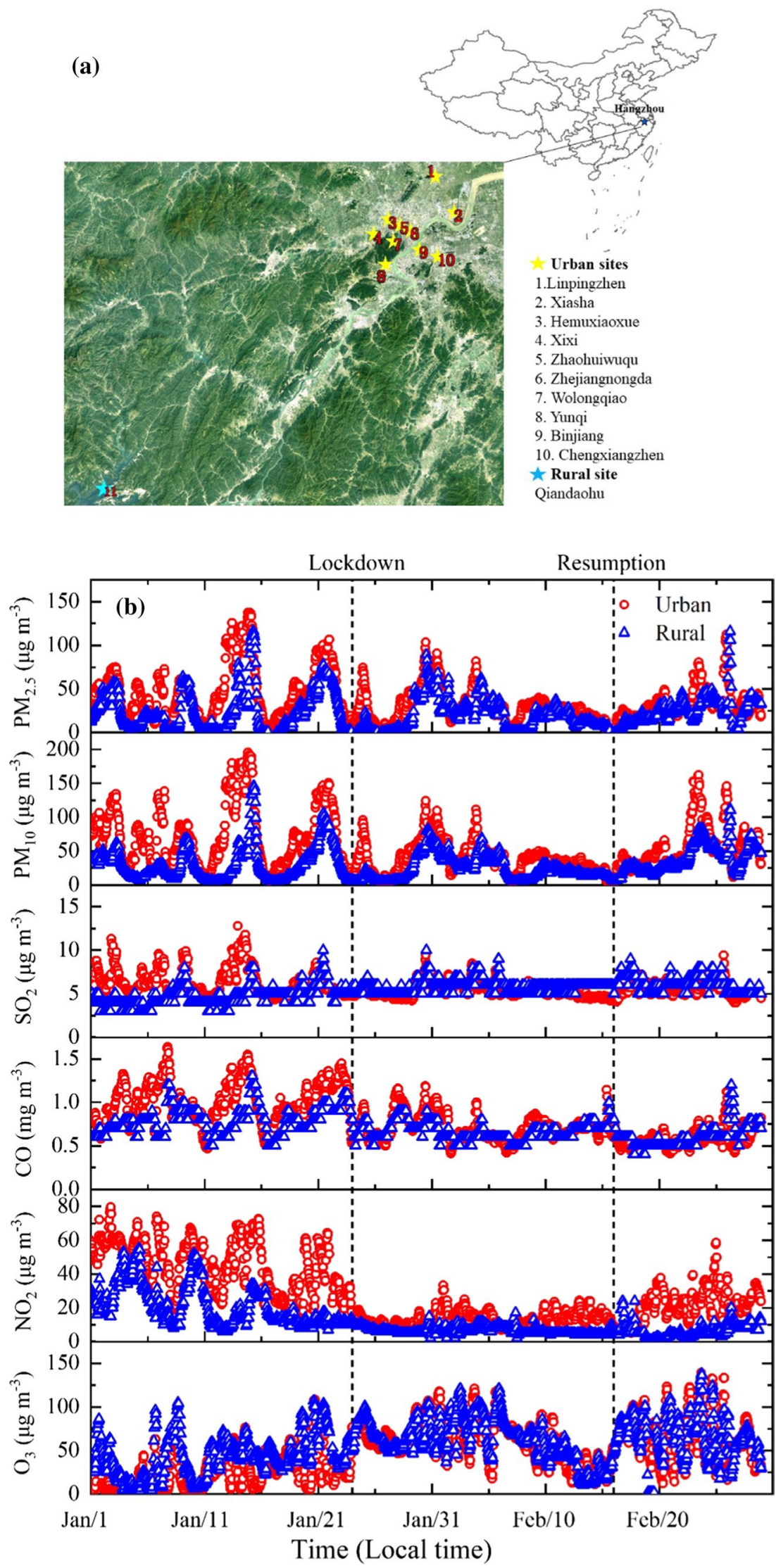
62 days for $\mathrm{PM}_{2.5}$ for the secondary Chinese Ambient Air Quality Standards (CAAQS): $\mathrm{PM}_{2.5}: 75 \mathrm{\mu g} \mathrm{m}^{-3}$ for $24 \mathrm{~h}$ average and $\mathrm{O}_{3}: 75$ ppbv for daily maximum $8 \mathrm{~h}$ (Zhang et al. 2018). During a severe haze episode from December 3-9, 2013, $\mathrm{PM}_{2.5}$ mean concentrations reached as high as $293.4 \pm 103.2 \mu \mathrm{g} \mathrm{m}^{-3}$ (Yu et al. 2014). Local emissions, complex atmospheric conditions, and regional transport exert combined effects on air pollution occurrence in Hangzhou (Yu et al. 2014; Li et al. 2015; Wu et al. 2018; Chen et al. 2020). On the other hand, Zhejiang, known for its thriving private sector, was the first province both to declare a highest level response to coronavirus on January 23, 2020 and to relax control measures and support work resumption (https://www.scmp.com/economy/chinaecono my/article/3049821/coronavirus-chinese-province-order s-relaxation-excessive). As the capital of Zhejiang province, Hangzhou city declared the first-level public health emergency response on January 23, 2020 (http://www.zj.gov.cn/ art/2020/1/26/art_1228996604_41859419.html).

A recent editorial underlines the importance and relevance of research in environmental chemistry to understand pandemics (Sharma et al. 2020). Here we study the impacts of the city lockdowns due to the COVID-19 outbreak on air quality in Hangzhou from January 1 to February 28, 2020. Our hypothesis was that air pollutants should have decreased during lockdown due to the absence of activities and traffic. This report reveals that, on the contrary, the concentrations of some air pollutants increased in both urban and rural areas.

\section{Experimental}

Hourly observational data of the six pollutants, $\mathrm{PM}_{2.5}$, $\mathrm{PM}_{10}, \mathrm{SO}_{2}, \mathrm{CO}, \mathrm{NO}_{2}, \mathrm{O}_{3}$, at the monitoring sites from January 1 to February 28, 2020, were collected from the website of China National Environmental Monitoring Center (CNEMC) (http://www.mee.gov.cn/hjzl/dqhj/). In addition data were acquired at 11 air quality monitoring stations are set up in Hangzhou, as shown in Fig. 1a, including 10 urban sites (Binjiang, Xiasha, Wolongqiao, Zhejiangnongda, Zhaohuiwuqu, Hemuxiaoxue, Linpingzhen, Xixi, Yunqi and Chengxiangzhen), and one rural background site (Qiandaohu), a lake park located about $170 \mathrm{~km}$ away from Hangzhou center. Average concentrations at the 10 urban sites were estimated to represent urban conditions, while the concentrations at the rural site were used to represent rural conditions. According to the China National Ambient Air Quality Standard (CNAAQS, GB3095-2012), the 24-hour average levels of each pollutant are regarded as valid only under if at least $20 \mathrm{~h}$ of hourly data are acquired. The $8 \mathrm{~h}-\mathrm{O}_{3}$ concentrations could be used only with more than $6 \mathrm{~h}$ available data for each $8 \mathrm{~h}$ period. In this study, the data in 2016, 2017, 2018 and 2019 were also used for comparison purpose.

Data of population (7.03 millions) and area $\left(16,596 \mathrm{~km}^{2}\right)$ of Hangzhou city were acquired from the Civil Affairs Ministry of the People's Republic of China (http://xzqh.mca. gov.cn/). The change of the Baidu Migration Scale Index to characterize the daily travel intensity index inside Hangzhou was downloaded from the public Baidu Maps website (http://qianxi.baidu.com/). Daily traffic density was calculated using the travel intensity index multiplied by population, and then divided by area.

\section{Results and discussion}

\section{Trends of air pollutants in early 2020}

\section{Overall trends}

Figure $1 \mathrm{~b}$ shows the time series of hourly concentrations of six pollutants at the urban and rural sites from January 1 to February 28, 2020, with the corresponding statistical values summarized in Table S1. To analyze the temporal variations of concentration and impacts of the lockdown, the entire study period was divided into three periods: before lockdown (BL, January 1-23), during lockdown (DL, January 24-February 15), and resumption (February 16-28). Results show that when comparing pollutant levels before and during lockdown, concentrations of $\mathrm{PM}_{2.5}, \mathrm{PM}_{10}, \mathrm{CO}$, $\mathrm{NO}_{2}$ decreased significantly, as expected. However, results also show an overall increase in ozone $\left(\mathrm{O}_{3}\right)$ levels both in both urban and rural areas. After February 15, these trends began to reverse due to the resumption of work and production activities.

\section{Particulate matter}

In the urban area, hourly average concentrations of $\mathrm{PM}_{2.5}$ decreased from $45.9 \pm 31.3 \mathrm{\mu g} \mathrm{m}^{-3}$ before lockdown to $29.6 \pm 19.5 \mu \mathrm{g} \mathrm{m}^{-3}$ during lockdown (Table S1). Similarly, at the rural site hourly $\mathrm{PM}_{2.5}$ levels decreased from $25.0 \pm 24.0$ to $20.1 \pm 16.9 \mu \mathrm{g} \mathrm{m}^{-3}$. In the same way, mean $\mathrm{PM}_{10}$ decreased significantly from 70.5 to $48.4 \mu \mathrm{g} \mathrm{m}^{-3}$ in the urban area and from 31.0 to $24.1 \mu^{-3} \mathrm{~g} \mathrm{~m}^{-3}$ at the rural site. Then, both $\mathrm{PM}_{2.5}$ and $\mathrm{PM}_{10}$ levels rose to higher values after resumption. It is known that coal combustion, biomass burning, vehicle emissions, and industrial emissions are the main anthropogenic sources of $\mathrm{PM}_{2.5}$ (Chow and Watson 2002; Cheng et al. 2014; Wu et al. 2016; Wang et al. 2016a; Mehmood et al. 2018, 2020). Therefore, our observed reduction in $\mathrm{PM}_{2.5}$ concentrations in Hangzhou city during lockdown is mainly due to limited industrial activity and traffic (Wang et al. 2012; Lyu et al. 2016; Zhang et al. 2017). In the 
rural area, reduction in $\mathrm{PM}_{2.5}$ and $\mathrm{PM}_{10}$ can be ascribed to restricted vehicle travel and lower impacts of regional transports. The consistent patterns of $\mathrm{PM}_{2.5}$ and $\mathrm{PM}_{10}$ in both urban and rural areas suggested the important contributions of anthropogenic emission sources and impacts of regional transport during the lockdown.

\section{Carbon monoxide}

CO decreased in both urban areas from 1.0 to $0.59 \mathrm{mg} \mathrm{m}^{-3}$, and in rural areas from 0.78 to $0.60 \mathrm{mg} \mathrm{m}^{-3}$. Since CO mainly originates from fossil fuel combustion and biomass burning (Zhang et al. 2009; Chai et al. 2014), decreasing anthropogenic emissions after reduction in industrial activities explain at least partly the $\mathrm{CO}$ patterns in both urban and rural areas.

\section{Sulfur dioxide}

$\mathrm{SO}_{2}$ mean concentrations in the urban area decreased from 6.3 to $5.3 \mu \mathrm{g} \mathrm{m}^{-3}$ after lockdown, then increased to $5.6 \mu \mathrm{g} \mathrm{m}^{-3}$ in the resumption period. However, surprisingly, $\mathrm{SO}_{2}$ mean concentrations at the rural site increased from 4.7 to $6.1 \mu \mathrm{g} \mathrm{m}^{-3}$ continuously during the entire period (Table S1). The unexpected increase in $\mathrm{SO}_{2}$ at the rural site is explained by the increase in coal consumption for heating coupled with inputs from the traditional fireworks during Spring Festival Eve and the Lantern Festival. Overall, $\mathrm{SO}_{2}$ concentrations remained low, which resulted from the implementation of control of $\mathrm{SO}_{2}$ emission (Fang et al. 2009), as observed in the Yangtze River Delta (Huang et al. 2012).

\section{Nitrogen dioxide}

Concentrations of $\mathrm{NO}_{2}$ at the urban sites dropped from 44.2 to $13.0 \mu \mathrm{g} \mathrm{m}^{-3}$ after lockdown, then slightly increased to $21.8 \mu \mathrm{g} \mathrm{m}^{-3}$ during resumption (Fig. 1, Table S1). At the rural site, $\mathrm{NO}_{2}$ levels decreased sharply from $21.0 \mu \mathrm{g} \mathrm{m}^{-3}$ to $6.8 \mu \mathrm{g} \mathrm{m}^{-3}$ during lockdown, then remained at very low levels of $6.4 \mathrm{\mu g} \mathrm{m}^{-3}$ during the resumption period. These findings are explained by lower $\mathrm{NO}_{\mathrm{x}}$ emissions from local vehicle emissions, power plants and industrial activities (Wang et al. 2014b, 2016b) during the lockdown, whereas rural decreases in $\mathrm{NO}_{2}$ concentrations might result from less vehicle emissions and less pollution transport from urban areas.

\section{Ozone}

Contrary to the dramatic decreases in $\mathrm{NO}_{2}$ during the lockdown, relatively low $\mathrm{O}_{3}$ levels in the urban area occurred before lockdown with almost all the values below $100 \mu \mathrm{g} \mathrm{m}^{-3}$, then began to reach higher concentrations during lockdown with the maximum over $139 \mu \mathrm{g} \mathrm{m}^{-3}$ as shown in Fig. 1. Mean concentrations of $\mathrm{O}_{3}$ increased from $24.6 \mu \mathrm{g} \mathrm{m}^{-3}$ before lockdown to $60.6 \mu \mathrm{g} \mathrm{m}^{-3}$ during lockdown in the urban area, whereas a lower increase in $\mathrm{O}_{3}$ levels from 42.0 to $62.9 \mathrm{\mu g} \mathrm{m}^{-3}$ occurred in the rural area (Table S1). Then, during the resumption, the mean $\mathrm{O}_{3}$ concentrations increased slightly in both urban and rural areas. As a secondary pollutant formed by photochemical reactions of nitrogen oxides $\left(\mathrm{NO}_{\mathrm{x}}\right)$ and volatile organic compounds (VOC) (Seinfeld and Pandis 2016), $\mathrm{O}_{3}$ will decrease with decrease in $\mathrm{NO}_{\mathrm{x}}$ in the $\mathrm{NO}_{\mathrm{x}}$ sensitive regime. The unexpected increase in $\mathrm{O}_{3}$ levels during lockdown with the decreases in $\mathrm{NO}_{2}$ is explained by the weakening of chemical titration of $\mathrm{O}_{3}$ by $\mathrm{NO}$ during the nighttime, resulting in increases in background $\mathrm{O}_{3}$ concentrations, as shown in Fig. 2.

In 2020, from 20:00 p.m. to 9:00 a.m. local time, the mean $\mathrm{O}_{3}$ concentrations for the non-photochemical reaction time period increased from $18.8 \mathrm{\mu g} \mathrm{m}^{-3}$ before lockdown to $53.7 \mu \mathrm{g} \mathrm{m}^{-3}$ during lockdown in urban areas, and from 35.6 to $58.0 \mu^{-3} \mathrm{~m}^{-3}$ in rural areas (Fig. 2). By comparison, in 2019 , the mean $\mathrm{O}_{3}$ concentrations for the same time periods increased from 10.0 to $35.9 \mathrm{\mu g} \mathrm{m}^{-3}$ in urban areas, and from 30.6 to $47.8 \mu \mathrm{g} \mathrm{m}^{-3}$ in rural areas. The higher levels during the lockdown time period are partly explained by higher atmosphere temperatures for late January/early February versus January 1-23. Apart from higher levels in 2020 for the whole time period, Fig. 2 shows meaningful higher $\mathrm{O}_{3}$ concentrations at night in 2020 relative to those in 2019. This confirms indirectly the fact that the $\mathrm{O}_{3}$ increase in 2020 during lockdown is due to the weakening of chemical titration of $\mathrm{O}_{3}$ by $\mathrm{NO}$ during the nighttime, resulting in increases in background $\mathrm{O}_{3}$ concentrations.

\section{Comparisons of air quality between 2019 and 2020}

Daily average concentrations of ambient $\mathrm{PM}_{2.5}, \mathrm{PM}_{10}, \mathrm{CO}$, $\mathrm{NO}_{2}, \mathrm{SO}_{2}$ and daily maximum $8 \mathrm{~h}-\mathrm{O}_{3}$ concentrations in 2020 relative to those in the same period of 2019 in the urban and rural areas are displayed in Fig. 3 and Table S1. PM 2.5 and $\mathrm{PM}_{10}$ concentrations in the urban areas decrease sharply on January 24 , and then remained below $75 \%$ during a few days January 24-27 (Fig. 3a,b). Similar drops of 96\% for $\mathrm{PM}_{2.5}$ and $95.6 \%$ for $\mathrm{PM}_{10}$ were observed at the rural site on January 26. $\mathrm{CO}$ and $\mathrm{SO}_{2}$ exhibited no significant change in the urban areas, whereas rising trends were observed at the rural site. This is explained by increasing biomass burning for residential heating or cooking in the rural area. At both urban and rural sites, $\mathrm{NO}_{2}$ decreased and the maximum drop appeared during January $24-30$, as expected. Daily maximum $8 \mathrm{~h}-\mathrm{O}_{3}$ concentrations were enhanced during almost all days in January and February in 2020 relative to 2019, 


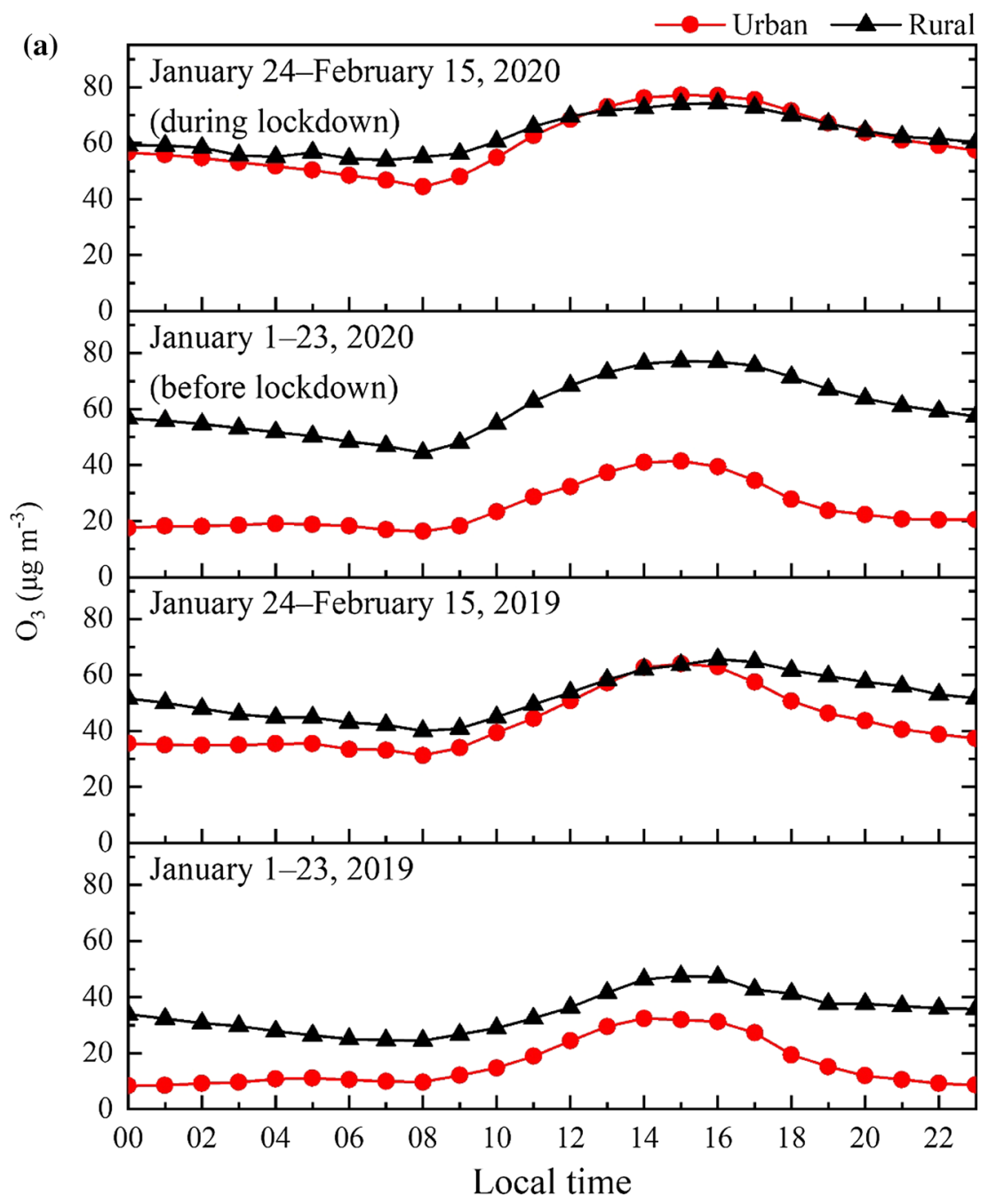

(b)
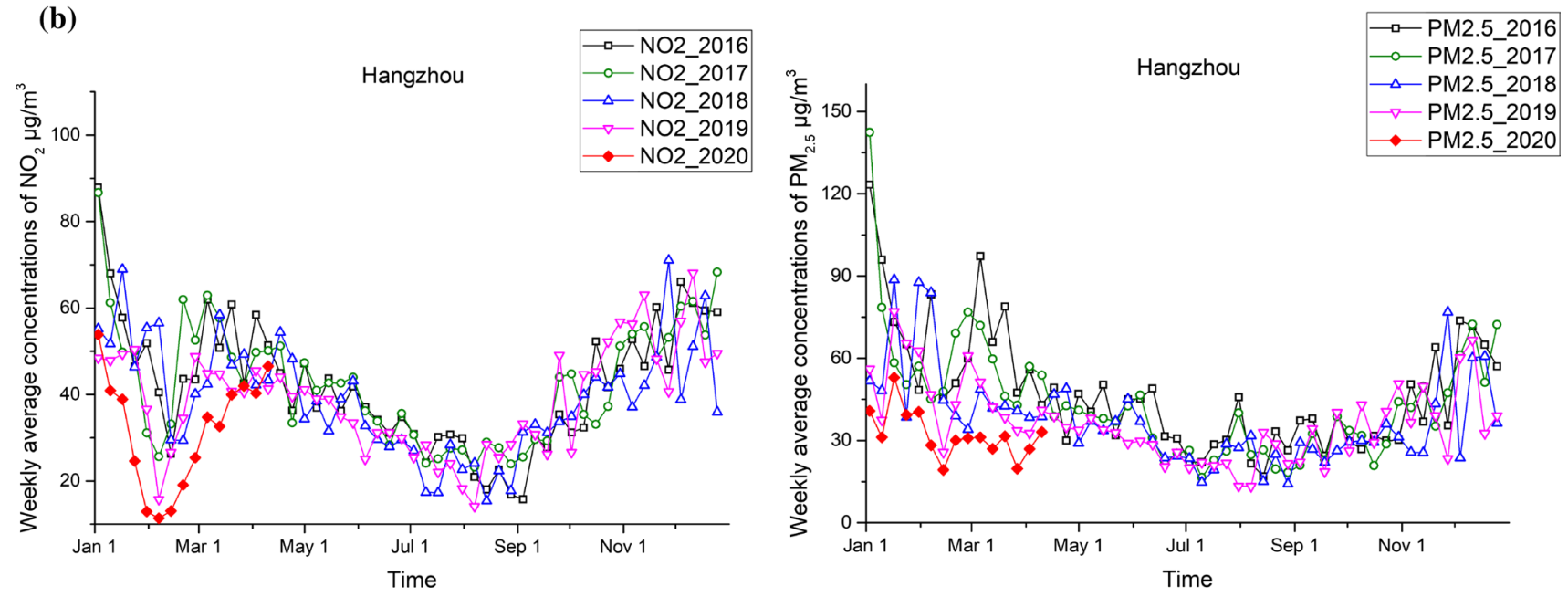

although the larger enhancements existed before lockdown in both urban and rural areas (Fig. 3).

For the urban area, before the lockdown period, January 1-23, 2020/2019 decreases amounted to $24.8 \%$ for $\mathrm{PM}_{2.5}$,

$19.8 \%$ for $\mathrm{PM}_{10}, 29.2 \%$ for $\mathrm{SO}_{2}, 14.1 \%$ for $\mathrm{CO}$ and $13.7 \%$ for $\mathrm{NO}_{2}$. By comparison, the decreases were much higher during the lockdown period, January 24-February 15: 42.7\% for $\mathrm{PM}_{2.5}, 47.9 \%$ for $\mathrm{PM}_{10}, 22.3 \% \mathrm{CO}$ and $58.4 \%$ for $\mathrm{NO}_{2}$; 
4 Fig. 2 a Diurnal variations of the mean $\mathrm{O}_{3}$ concentrations for the periods of before (BL) and during (DL) lockdowns in the urban and rural areas in Hangzhou in 2020 and 2019; b Comparisons of the weekly mean values of $\mathrm{NO}_{2}$ and $\mathrm{PM}_{2.5}$ concentrations in the years of 2016, 2017, 2018, 2019 and 2020. Before Lockdown (BL), During Lockdown (DL), and Resumption denote the periods of January 1-January 23, January 24-February 15, and February 16-February 28 , respectively. The diurnal variations of mean $\mathrm{O}_{3}$ concentrations for the periods of $\mathrm{BL}$ and $\mathrm{DL}$ in $(\mathrm{a}, \mathrm{b})$ clearly indicate that the mean $\mathrm{O}_{3}$ concentrations for the non-photochemical reaction times from 20:00 PM to 9:00 AM (local time) during lockdown in 2020 were 53.7 and $58.0 \mu \mathrm{g} \mathrm{m}^{-3}$ in the urban and rural areas, respectively, much higher than the corresponding values (i.e., 18.8 and $35.6 \mu \mathrm{g} \mathrm{m}^{-3}$ in the urban and rural areas, respectively) before lockdown

except for $\mathrm{SO}_{2}(28.6 \%)$ (Table $\left.\mathrm{S} 1\right)$. Higher decreases after January 24 reveal the reductions in industrial activities and traffic in Hangzhou. The similar $\mathrm{SO}_{2}$ changes are in agreement with the contribution of coal combustion for heating and firework emissions during lockdown.

For the rural area, only $\mathrm{PM}_{2.5}, \mathrm{PM}_{10}$, and $\mathrm{NO}_{2}$ showed significantly higher decreases of $-18.5 \%,-39.6 \%,-48.0 \%$ during the lockdown period, respectively, compared with the corresponding $4.4 \%,-27.0 \%,-4.8 \%$ before lockdown (Table S1). Whereas $\mathrm{SO}_{2}$ and $\mathrm{CO}$ exhibited weak decreases during lockdown, $\mathrm{O}_{3}$ concentrations exhibited an increase during the whole period at all sites relative to those in 2019. With similar decrease percentages of $\mathrm{NO}_{2}$ at the urban sites $(-58.4 \%)$ and rural site (-48.0\%) during January 24-February 15 , larger enhancement percentages of $\mathrm{O}_{3}$ were observed at the urban (22.2\%) relative to rural (15.7\%) sites in 2020 in comparison to those in 2019. Moreover, the weekly mean concentrations of $\mathrm{NO}_{2}$ and $\mathrm{PM}_{2.5}$ in 2020 were consistently lower than those in the same periods of 2016, 2017, 2018 and 2019, due to the emission reductions because of the city lockdown (see Fig. 3b) in addition to the possible effects from the differences in meteorological conditions for each year.

\section{Correlations between $\mathrm{NO}_{2}$ and city traffic index in Hangzhou}

$\mathrm{NO}_{\mathrm{x}}$, including $\mathrm{NO}$ and $\mathrm{NO}_{2}$, are major precursors of $\mathrm{PM}_{2.5}$ and $\mathrm{O}_{3}$, and are primarily emitted as NO from anthropogenic combustion sources including transportation, power plants, industries and residential combustion, and from natural sources such as soil, lightning, and wildfire. $\mathrm{NO}_{\mathrm{x}}$ is an excellent tracer of human activity (Chen et al. 2013; $\mathrm{Yu}$ et al. 2014). Our results show that $\mathrm{NO}_{2}$ concentrations in both urban and rural areas in Hangzhou dropped sharply during the lockdown (Figs. 1, 2). Higher temperatures, stronger sunlight and increasing precipitation in February can decrease $\mathrm{NO}_{2}$ relative to those in January for fixed emissions in Hangzhou.
To understand the impact of traffic flows on the $\mathrm{NO}_{2}$ in Hangzhou, Fig. 4a displays changes in daily traffic density against the changes in daily $\mathrm{NO}_{2}$ mean concentrations in 2020 relative to those in 2019 . We found a significant positive correlation (correlation coefficient $(r)=0.51$ ) between the change in traffic density and $\mathrm{NO}_{2}$ in the urban area. This finding reinforces the hypothesis by which traffic reduction is at least partly responsible for $\mathrm{NO}_{2}$ decreases. By contrast, traffic density and $\mathrm{NO}_{2}$ is very weakly correlated at the rural site $(r=0.18)$. This suggests that $\mathrm{NO}_{2}$ does not mainly originate from local traffic in rural areas, but may come from long-distance transport. It has been shown that regional transport of $\mathrm{NO}_{\mathrm{x}}$ and VOCs from urbanized upwind areas can lead to high $\mathrm{O}_{3}$ levels (Sikder et al. 2011; Monteiro et al. 2012; Yu et al. 2006; Li et al., 2015). Moreover, $\mathrm{NO}_{2}$ exhibits a strong correlation with $\mathrm{PM}_{2.5}$ in the urban area of Hangzhou $(r=0.51, P<0.05)$ (Fig. 3d), indicating local vehicle emissions are an important source of $\mathrm{PM}_{2.5}$.

\section{Inter-species correlations in the observations}

Negative correlations are found between daily maximum 8-h $\mathrm{O}_{3}$ and mean $\mathrm{NO}_{2}$ levels in both urban and rural areas (Fig. 4b). This suggests a VOC-limited regime of $\mathrm{O}_{3}$ formation prevailing during winter time periods in Hangzhou, in agreement with conclusions reported in Shanghai and Nanjing (Ding et al. 2013; Gu et al. 2020). Notably, a significantly weaker positive response is observed under low $\mathrm{NO}_{2}$ levels, below $20 \mu \mathrm{g} \mathrm{m}^{-3}$, showing the shift of $\mathrm{O}_{3}$ production to the transition regime or even $\mathrm{NO}_{\mathrm{x}}$-limited regime, especially in the rural area. At low $\mathrm{VOC} / \mathrm{NO}_{\mathrm{x}}$ ratios, chain termination reaction of $\mathrm{OH}$ and $\mathrm{NO}_{2}$ produces a VOC-limited regime. Conversely, at high $\mathrm{VOC} / \mathrm{NO}_{\mathrm{x}}$ ratios, the primary chain termination and propagation reactions involve $\mathrm{OH}$ and VOCs, and oxidation of $\mathrm{NO}$ by $\mathrm{HO}_{2}$ and $\mathrm{RO}_{2}$, respectively, producing an $\mathrm{NO}_{\mathrm{x}}$-limited regime (Seinfeld and Pandis 2016).

Little correlation was observed between daily mean $\mathrm{PM}_{2.5}$ and maximum 8-h $\mathrm{O}_{3}$ concentrations (Fig. 4c). Here, we displayed boxplots of maximum 8-h $\mathrm{O}_{3}$ concentrations versus daily mean $\mathrm{PM}_{2.5}$ concentrations. The initial $\mathrm{PM}_{2.5}$ bin was $5 \mu \mathrm{g} \mathrm{m}^{-3}$ and rose to 10 or $15 \mu \mathrm{g} \mathrm{m}^{-3}$ under high $\mathrm{PM}_{2.5}$ concentrations. Overall, median maximum 8-h $\mathrm{O}_{3}$ concentrations increased along with daily mean $\mathrm{PM}_{2.5}$ at low to moderate $\mathrm{PM}_{2.5}$ levels, then declined for daily $\mathrm{PM}_{2.5}$ concentrations $>40 \mu \mathrm{g} \mathrm{m}^{-3}$ as shown in Fig. $4 \mathrm{c}$. The positive correlation between $\mathrm{PM}_{2.5}$ and $\mathrm{O}_{3}$ is associated with the conversion of gaseous organics to $\mathrm{PM}_{2.5}$ under $\mathrm{OH}$ and $\mathrm{O}_{3}$ oxidation, forming secondary organic aerosols (Seinfeld and Pandis, 2016). The observed decline in $\mathrm{O}_{3}$ driven by high $\mathrm{PM}_{2.5}$ concentrations could be attributed to reduced solar radiation due to extinction by particulate matter, depositional 
Fig. 3 Change percentages of the daily average concentrations of ambient $\mathrm{PM}_{2.5}, \mathrm{PM}_{10}$, $\mathrm{CO}$, $\mathrm{NO}_{2}, \mathrm{SO}_{2}$ and daily maximum $8 \mathrm{~h}-\mathrm{O}_{3}$ concentration during January and February in 2020 relative to those in 2019 in Hangzhou in (a) the urban area and (b) the rural area. As indicated in Fig. 3a and Fig. 3b, $\mathrm{PM}_{2.5}$ and $\mathrm{PM}_{10}$ concentrations in the urban areas experienced a sharp decrease on January 24 , and then remained relatively larger negative percentages (below $-75 \%$ ) during a few days from January 24-27. The simultaneous quick drops after January 24 also occurred for $\mathrm{PM}_{2.5}$ and $\mathrm{PM}_{10}$ levels at the rural site with the minimum values as low as $-96 \%$ and $-95.6 \%$ on January 26 , respectively

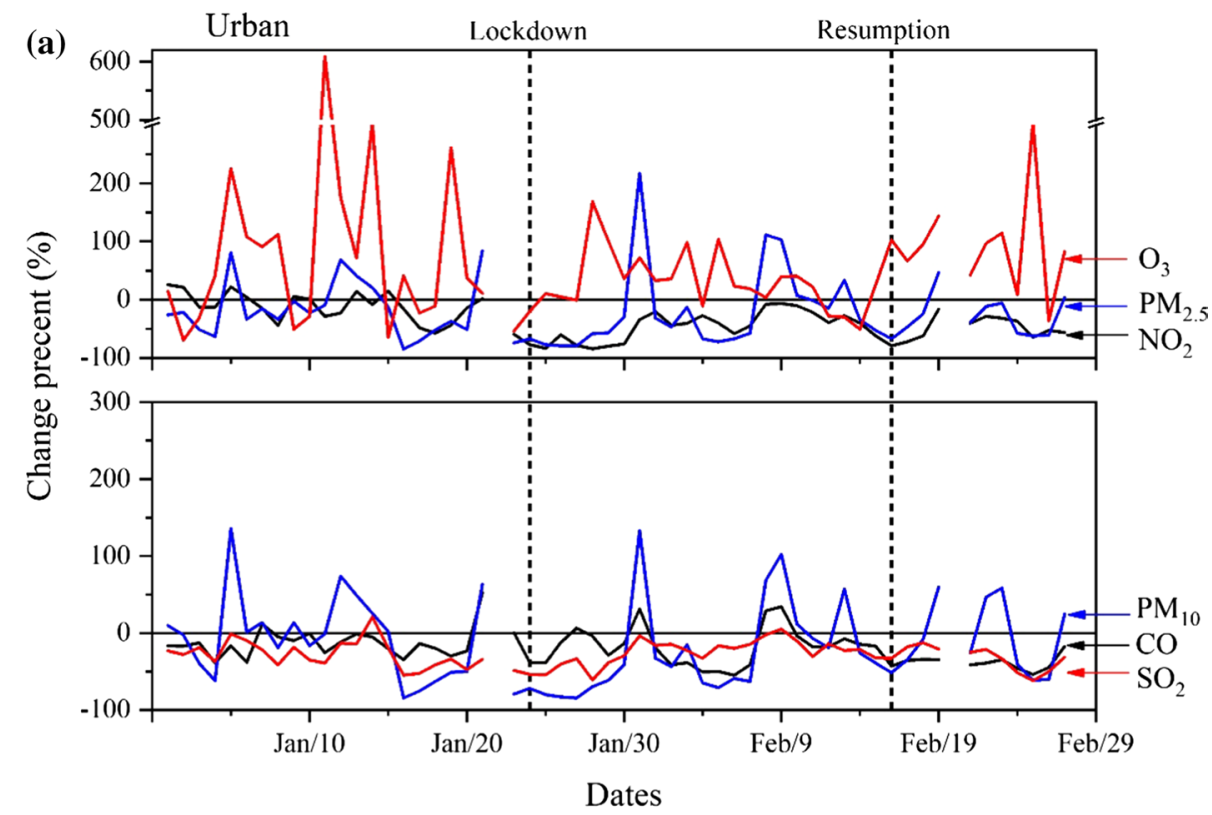

(b)

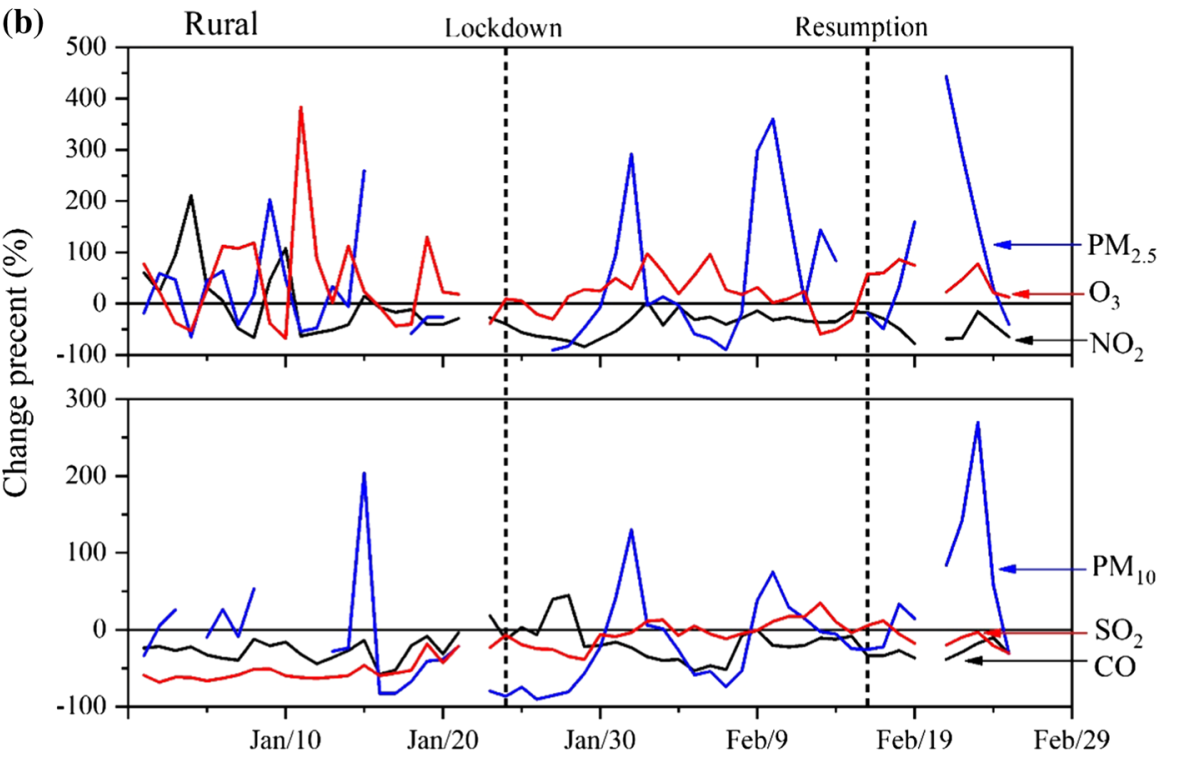

Dates sink of $\mathrm{HO}_{2}$ and $\mathrm{NO}_{\mathrm{x}}$ radicals, and chemical titration of $\mathrm{NO}$ (Buysse et al. 2019; Li et al. 2019; Yu et al., 2014).

\section{Conclusion}

We investigated the effects of city lockdowns on air quality based on ground-based observations in both urban and rural areas in Hangzhou. Results indicate that during lockdown relative to the period before lockdown, concentrations of $\mathrm{PM}_{2.5}, \mathrm{PM}_{10}, \mathrm{CO}$, and $\mathrm{NO}_{2}$ displayed significantly decreasing trends, as expected, while an overall rising trend was observed for $\mathrm{O}_{3}$ in both urban and rural areas, which is explained by the 'absence' of
$\mathrm{NO}_{\mathrm{x}}$. The sharp decreases in the $\mathrm{NO}_{2}$ concentrations in the urban area during the lockdown were mainly a result of direct traffic emission reductions, whereas in the rural area decreases were mainly from less regional transport. $\mathrm{SO}_{2}$ mean concentrations in the urban area decreased from 6.3 to $5.3 \mu \mathrm{g} \mathrm{m}^{-3}$, as expected, but increased in rural areas from 4.7 to $5.8 \mu \mathrm{g} \mathrm{m}^{-3}$, a consequence of increases in coal combustion for heating and firework emissions. Mean $\mathrm{O}_{3}$ concentrations increased significantly from 24.6 before lockdown to $60.6 \mathrm{\mu g} \mathrm{m}^{-3}$ during lockdown in the urban area, whereas the corresponding rural $\mathrm{O}_{3}$ levels modestly increased from 42.0 to $62.9 \mu \mathrm{g} \mathrm{m}^{-3}$. Here the $\mathrm{O}_{3}$ increase in the urban areas is explained by the reduction in $\mathrm{NO}_{\mathrm{x}}$ emissions. Overall, the city lockdown improved air quality 
(a)

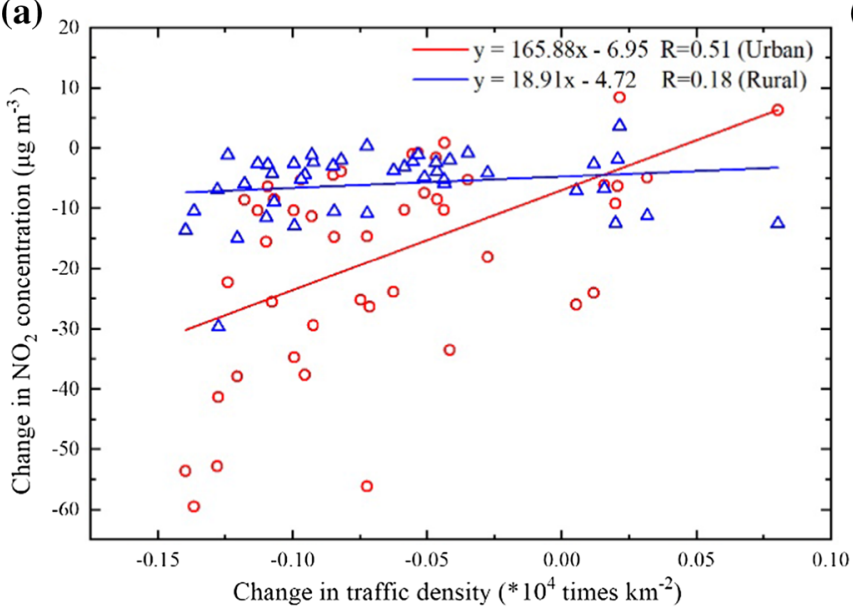

(c)

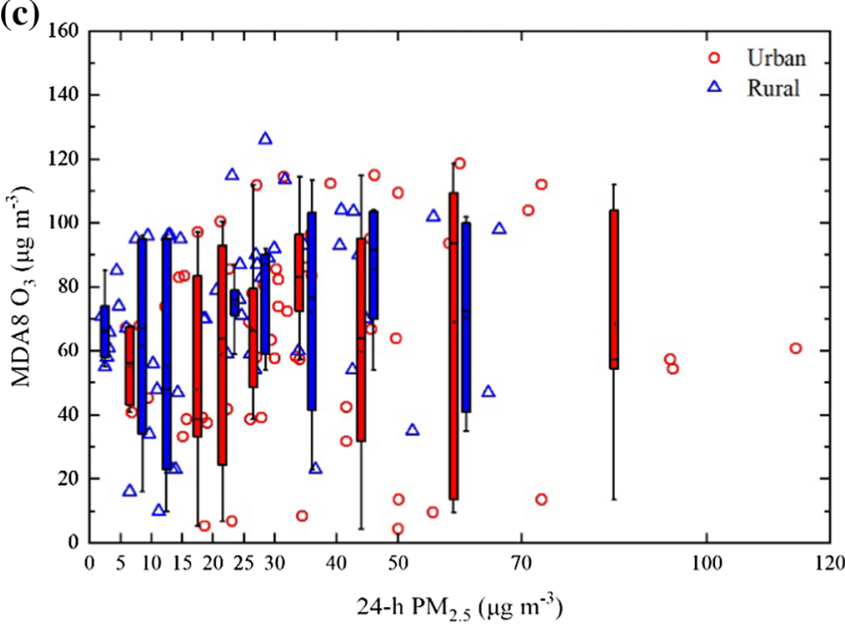

Fig. 4 a Scatter plots and linear regressions of the changes in daily traffic density against changes in daily concentrations of $\mathrm{NO}_{2}$ during January and February in 2020 relative to 2019 at urban and rural sites. b Scatter plots and linear regression of daily (24-h) $\mathrm{NO}_{2}$ against maximum 8-h $\mathrm{O}_{3}$ (MDA8 $\mathrm{O}_{3}$ ) during January 1-February 28, 2020, at urban and rural sites. $\mathbf{c}$ Scatter plots of $24-\mathrm{h} \mathrm{PM}_{2.5}$ against MDA8 $\mathrm{O}_{3}$ and boxplots of MDA8 $\mathrm{O}_{3}$ binned by daily (24-h) $\mathrm{PM}_{2.5}$ (at least three data points required) during January 1-February 28, 2020 at urban and rural sites. The boxes represent the 75th, 50th, and 25th percentiles from top to bottom, the whiskers and solid squares denote

by reducing $\mathrm{PM}_{2.5}, \mathrm{PM}_{10}, \mathrm{CO}$, and $\mathrm{NO}_{2}$, but also decreased air quality by augmenting $\mathrm{O}_{3}$ in both urban and rural areas and $\mathrm{SO}_{2}$ in the rural area in Hangzhou.

Acknowledgements This work was partially supported by the Department of Science and Technology of China (Nos. 2016YFC0202702, 2018YFC0213506, and 2018YFC0213503), National Research Program for Key Issues in Air Pollution Control in China (No. DQGG0107), and National Natural Science Foundation of China (Nos. 21577126 and 41561144004). Part of this work was also supported by the "Zhejiang 1000 Talent Plan" and Research Center for Air Pollution and Health in Zhejiang University. Pengfei Li is supported by Initiation Fund for Introducing Talents of Hebei Agricultural University (412201904). (b)

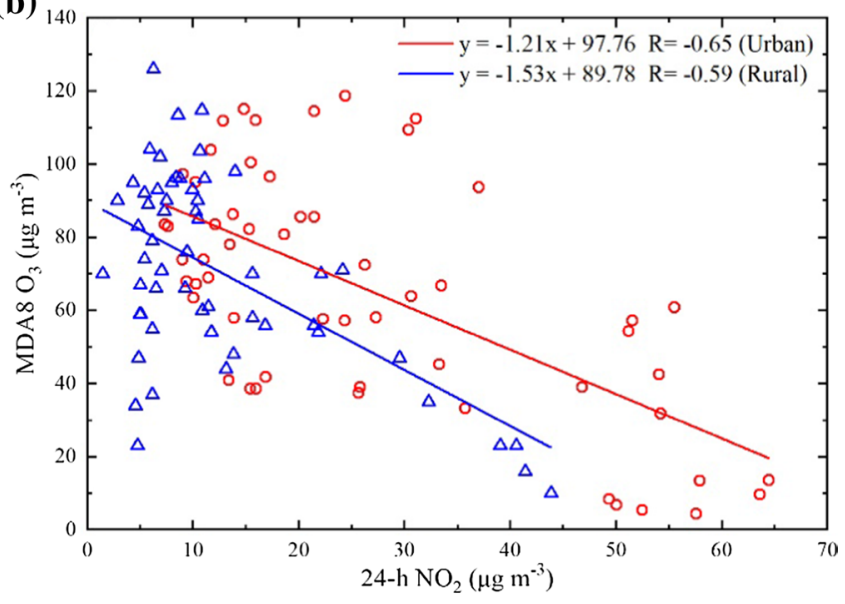

(d)

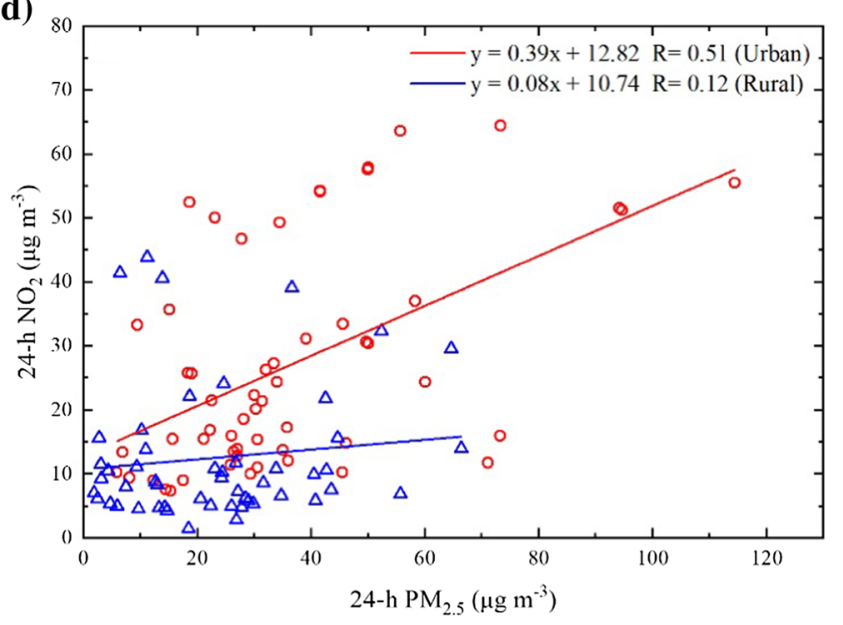

1.5 times of IQR and mean values, respectively. d Scatter plots and linear regression of 24-h $\mathrm{PM}_{2.5}$ against 24-h $\mathrm{NO}_{2}$ during January 1February 28, 2020 at urban and rural sites. The significant positive correlation $(r=0.51)$ between the change in traffic density and $\mathrm{NO}_{2}$ in the urban area of Hangzhou in Fig. 4a further explains $\mathrm{NO}_{2}$ decreases during lockdown in 2020 due to direct traffic emission reductions. A weak positive correlation between the change in traffic density and $\mathrm{NO}_{2}$ at the rural site in Fig. 4a indicates that $\mathrm{NO}_{2}$ in the rural area did not arise mainly from direct traffic emissions rather from regional transport

\section{References}

Buysse CE, Kaulfus A, Nair U, Jaffe DA (2019) Relationships between particulate matter, ozone, and nitrogen oxides during urban smoke events in the western US. Environ Sci Technol 53:12519-12528. https://doi.org/10.1021/acs.est.9b05241

Chai FH, Gao J, Chen ZX, Wang SL, Zhang YC, Zhang JQ, Zhang HF, Yun YR, Ren C (2014) Spatial and temporal variation of particulate matter and gaseous pollutants in 26 cities in China. J Environ Sci (China) 26:75-82. https://doi.org/10.1016/S1001 -0742(13)60383-6

Chen Y, Ebenstein A, Greenstone M, Li H (2013) Evidence on the impact of sustained exposure to air pollution on life expectancy 
from China's Huai River policy. Proc Natl Acad Sci U S A 110:12936-12941. https://doi.org/10.1073/pnas.1300018110

Chen X, Yu SC, Wang LQ, Li Z, Zhang YB, Li MY, Mehmood K, Liu WP, Li PF, Lichtfouse E, Rosenfeld D, Seinfeld JH (2020) Common source areas of air pollution vary with haze intensity in the Yangtze River Delta, China. Environ Chem Lett 18:957-965. https://doi.org/10.1007/s10311-020-00976-0

Cheng Z, Wang S, Fu X, Watson JG, Jiang J, Fu Q, Chen C, Xu B, Yu J, Chow JC, Hao J (2014) Impact of biomass burning on haze pollution in the Yangtze River delta, China: a case study in summer 2011. Atmos Chem Phys 14:4573-4585. https://doi.org/10.5194/ acp-14-4573-2014

China daily (2020) Smog still a problem amid viral contagion. http:// ex.chinadaily.com.cn/exchange/partners/45/rss/channel/www/ columns/2n8e04/stories/WS5e446535a31012821727718d.html

Chow JC, Watson JG (2002) Review of $\mathrm{PM}_{25}$ and $\mathrm{PM}_{10}$ apportionment for fossil fuel combustion and other sources by the Chemical Mass Balance receptor model. Energy Fuels 16:222-260. https://doi. org/10.1021/ef0101715

Ding AJ, Fu CB, Yang XQ, Sun JN, Zheng LF, Xie YN, Herrmann E, Nie W, Petäjä T, Kerminen VM, Kulmala M (2013) Ozone and fine particle in the western Yangtze River Delta: an overview of 1 yr data at the SORPES station. Atmos Chem Phys 13:58135830. https://doi.org/10.5194/acp-13-5813-2013

Ding AJ, Huang X, Nie W, Chi X, Xu Z, Zheng L, Xu Z, Xie Y, Qi X, Shen Y, Sun P, Wang J, Wang L, Sun J, Yang XQ, Qin W, Zhang X, Cheng W, Liu W, Pan L, Fu C (2019) Significant reduction of $\mathrm{PM}_{2.5}$ in eastern China due to regional-scale emission control: evidence from SORPES in 2011-2018. Atmos Chem Phys 19:11791-11801. https://doi.org/10.5194/acp-19-11791-2019

Fang M, Chan CK, Yao X (2009) Managing air quality in a rapidly developing nation: china. Atmos Environ 43:79-86. https://doi. org/10.1016/j.atmosenv.2008.09.064

Gu Y, Li K, Xu JM, Liao H, Zhou GQ (2020) Observed dependence of surface ozone on increasing temperature in Shanghai. China Atmos Environ 221:117108. https://doi.org/10.1016/j.atmos env.2019.117108

Guan WJ, Ni ZY, Hu Y, Liang W, Ou C, He J, Liu L, Shan H, Lei C, Hui D, Du B, Li L, Zeng G, Yuen K, Chen R, Tang C, Wang T, Chen P, Xiang J, Li S, Wang J, Liang Z, Peng YLYYP, Wang J, Liu J, Chen Z, Li G, Zheng Z, Qiu S, Luo J, Ye C, Zhu S, Zhong N (2020) Clinical characteristics of coronavirus disease 2019 in China. N Engl J Med 382:1708-1720. https://doi.org/10.1056/ NEJMoa2002032

Huang K, Zhuang G, Lin Y, Fu JS, Wang Q, Liu T, Zhang R, Jiang Y, Deng C, Fu Q, Hsu NC, Cao B (2012) Typical types and formation mechanisms of haze in an Eastern Asia megacity, Shanghai. Atmos Chem Phys 12:105-124. https://doi.org/10.5194/ acp-12-105-2012

Huang C, Wang Y, Li X et al (2020) Clinical features of patients infected with 2019 novel coronavirus in Wuhan, China. Lancet 395:497-506. https://doi.org/10.1016/S0140-6736(20)30183-5

Li H, Li L, Huang C, An JY, Yan RS, Huang HY, Wang YJ, Lu Q, Wang Q, Lou SR, Wang HL, Zhou M, Tao SK, Qiao LP, Chen MH (2015) Ozone source apportionment at urban area during a typical photochemical pollution episode in the summer of 2013 in the Yangtze River Delta. Huanjing Kexue Environ Sci 36:1-10. https://doi.org/10.13227/j.hjkx.2015.01.001

Li P, Wang LQ, Guo P, Yu SC, Mehmood K, Wang S, Liu WP, Seinfeld JH, Zhang Y, Wong DC, Alapaty K, Pleim J, Mathur R (2017) High reduction of ozone and particulate matter during the 2016 G-20 summit in Hangzhou by forced emission controls of industry and traffic. Environ Chem Lett 15:709-715. https://doi. org/10.1007/s10311-017-0642-2

Li K, Jacob DJ, Liao H, Zhu J, Shah V, Shen L, Bates KH, Zhang Q, Zhai S (2019) A two-pollutant strategy for improving ozone and particulate air quality in China. Nat Geosci 12:906-910. https:// doi.org/10.1038/s41561-019-0464-x

Liu H, Liu C, Xie Z, Li Y, Huang X, Wang S, Xu J, Xie P (2016) A paradox for air pollution controlling in China revealed by "aPEC Blue" and "parade Blue". Sci Rep. https://doi.org/10.1038/srep3 4408

Lyu X, Chen N, Guo H, Zeng L, Zhang W, Shen F, Quan J, Wang N (2016) Chemical characteristics and causes of airborne particulate pollution in warm seasons in Wuhan, central China. Atmos Chem Phys 16:10671-10687. https://doi.org/10.5194/acp-1610671-2016

MEE (Ministry of Ecology and Environment of China) (2020) Why was there the heavy pollution in Beijing-Tianjin-Hebei (BTH) and its surrounding areas? Five experts answer questions. https:// weibo.com/ttarticle/p/show?id=2309404470856360263747

Mehmood K, Chang SC, Yu SC, Wang LQ, Li PF, Li Z, Liu WP (2018) Spatial and temporal distributions of air pollutant emissions from open crop straw and biomass burnings in China from 2002 to 2016. Environ Chem Lett 16:301-309. https://doi.org/10.1007/ s10311-017-0675-6

Mehmood K, Wu YJ, Wang LQ, Yu SC, Li PF, Chen X, Li Z, Zhang YB, Li MY, Liu WP, Wang YS, Liu ZR, Zhu YN, Rosenfeld D, Seinfeld JH (2020) Relative effects of open biomass burning and open crop straw burning on haze formation over central and eastern China: modeling study driven by constrained emissions. Atmos Chem Phys 20:2419-2443. https://doi.org/10.5194/ acp-20-2419-2020

Monteiro A, Strunk A, Carvalho A, Tchepel O, Miranda AI, Borrego C, Saavedra S, Rodríguez A, Souto J, Casares J, Friese E, Elbern $\mathrm{H}$ (2012) Investigating a high ozone episode in a rural mountain site. Environ Pollut 162:176-189. https://doi.org/10.1016/j.envpo 1.2011 .11 .008

NASA (2020) Airborne Nitrogen Dioxide Plummets Over China. https ://earthobservatory.nasa.gov/images/146362/airborne-nitrogendioxide-plummets-over-china?utm $=$ carousel

Pope CA (2000) Epidemiology of fine particulate air pollution and human health: biologic mechanisms and who's at risk? Environ Health Perspect 108:713-723. https://doi.org/10.2307/3454408

Rosenfeld D, Zhu YN, Wang MH, Zheng YT, Goren T, Yu SC (2019) Aerosol-driven droplet concentrations dominate coverage and water of oceanic low-level clouds. Science 363:1-9. https://doi. org/10.1126/science.aav0566

Seinfeld JH, Pandis SN (2016) Atmospheric chemistry and physics: from air pollution to climate change. Wiley, New York, pp 1-1326

Sharma VK, Jinadatha C, Lichtfouse E (2020) Environmental chemistry is most relevant to study coronavirus pandemics. Environ Chem Lett. https://doi.org/10.1007/s10311-020-01017-6

Sikder HA, Suthawaree J, Kato S, Kajii Y (2011) Surface ozone and carbon monoxide levels observed at Oki, Japan: regional air pollution trends in East Asia. J Environ Manage 92:953-959. https ://doi.org/10.1016/j.jenvman.2010.10.062

Tian H, Liu Y, Li Y, Wu C, Chen B, Kraemer M, Li B, Cai J, Xu B, Yang Q, Wang B, Yang P, Cui Y, Song Y, Zheng P, Wang Q, Bjornstad O, Yang R, Grenfell B, Pybus O, Dye C (2020) An investigation of transmission control measures during the first 50 days of the COVID-19 epidemic in China. Science 80(368):638-642. https://doi.org/10.1126/science.abb6105

van Donkelaar A, Martin RV, Brauer M, Kahn R, Levy R, Verduzco C, Villeneuve PJ (2010) Global estimates of ambient fine particulate matter concentrations from satellite-based aerosol optical depth: development and application. Environ Health Perspect 118:847855. https://doi.org/10.1289/ehp.0901623

Wang ZS, Wu T, Shi GL, Fu X, Tian YZ, Feng YC, Wu XF, Wu G, Bai ZP, Zhang WJ (2012) Potential source analysis for $\mathrm{PM}_{10}$ and $\mathrm{PM}_{2.5}$ in autumn in a Northern City in China. Aerosol Air Qual Res 12:39-48. https://doi.org/10.4209/aaqr.2011.04.0045 
Wang Y, Yao L, Wang L, Liu Z, Ji D, Tang G, Zhang J, Sun Y, Bo $\mathrm{H}$, Xin J (2014a) Mechanism for the formation of the January 2013 heavy haze pollution episode over central and eastern China. Sci China Earth Sci 57:14-25. https://doi.org/10.1007/s1143 0-013-4773-4

Wang Y, Ying Q, Hu J, Zhang H (2014b) Spatial and temporal variations of six criteria air pollutants in 31 provincial capital cities in China during 2013-2014. Environ Int 73:413-422. https://doi. org/10.1016/j.envint.2014.08.016

Wang JZ, Ho SSH, Ma SX, Cao JJ, Dai WT, Liu SX, Shen ZX, Huang RJ, Wang GH, Han YM (2016a) Characterization of $\mathrm{PM}_{2.5}$ in Guangzhou, China: uses of organic markers for supporting source apportionment. Sci Total Environ 550:961-971. https://doi. org/10.1016/j.scitotenv.2016.01.138

Wang K, Tian H, Hua S, Zhu C, Gao J, Xue Y, Hao J, Wang Y, Zhou J (2016b) A comprehensive emission inventory of multiple air pollutants from iron and steel industry in China: temporal trends and spatial variation characteristics. Sci Total Environ 559:7-14. https://doi.org/10.1016/j.scitotenv.2016.03.125

Wang G, Cheng SY, Wei W, Yang XW, Wang XQ, Jia J, Lang JL, Lv $\mathrm{Z}$ (2017) Characteristics and emission-reduction measures evaluation of $\mathrm{PM}_{2.5}$ during the two major eventsAPEC and Parade. Sci Total Environ 595:81-92. https://doi.org/10.1016/j.scito tenv.2017.03.231

World Health Organization. Coronavirus disease (COVID-19) outbreak. https://www.who.int/emergencies/diseases/novel-coron avirus-2019

Wu J, Xu C, Wang Q, Cheng W (2016) Potential Sources and Formations of the $\mathrm{PM}_{2.5}$ Pollution in Urban Hangzhou. Atmosphere 7:100. https://doi.org/10.3390/atmos7080100

Wu YJ, Wang P, Yu SC, Wang LQ, Li PF, Li Z, Mehmood K, Liu WP, Wu J, Lichtfouse E, Rosenfeld D, Seinfeld JH (2018) Residential emissions predicted as a major source of fine particulate matter in winter over the Yangtze River Delta, China. Environ Chem Lett 16:1117-1127. https://doi.org/10.1007/s10311-018-0735-6

Xing J, Zhang Y, Wang S, Liu X, Cheng S, Zhang Q, Chen Y, Streets DG, Jang C, Hao J, Wang W (2011) Modeling study on the air quality impacts from emission reductions and atypical meteorological conditions during the 2008 Beijing Olympics.
Atmos Environ 45:1786-1798. https://doi.org/10.1016/j.atmos env.2011.01.025

Yu SC, Mathur R, Kang DW, Schere K, Eder B, Pleim J (2006) Performance and diagnostic evaluation of ozone predictions by the eta-community multiscale air quality forecast system during the 2002 new England air quality study. J Air Waste Manag Assoc 56:1459-1471. https://doi.org/10.1080/10473289.2006.10464554

Yu SC, Zhang Q, Yan R, Liu BCÁW (2014) Origin of air pollution during a weekly heavy haze episode in Hangzhou, China. Environ Chem Lett 12:543-550. https://doi.org/10.1007/s1031 1-014-0483-1

Zhang Q, Streets DG, Carmichael GR, He KB, Huo H, Kannari A, Klimont Z, Park IS, Reddy S, Fu JS, Chen D, Duan L, Lei Y, Wang LT, Yao ZL (2009) Asian emissions in 2006 for the NASA INTEX-B mission. Atmos Chem Phys 9:5131-5153. https://doi. org/10.5194/acp-9-5131-2009

Zhang XX, Sharratt B, Chen X, Wang ZF, Liu Li Y, Guo YH, Li J, Chen HS, Yang WY (2017) Dust deposition and ambient PM $_{10}$ concentration in northwest China: spatial and temporal variability. Atmos Chem Phys 17:1699-1711. https://doi.org/10.5194/ acp-17-1699-2017

Zhang G, Xu H, Qi B, Du R, Gui K, Wang H, Jiang W, Liang L, Xu W (2018) Characterization of atmospheric trace gases and particulate matter in Hangzhou, China. Atmos Chem Phys 18:1705-1728. https://doi.org/10.5194/acp-18-1705-2018

Zhang Q, Zheng Y, Tong D, Shao M, Wang S, Zhang Y, Xu X, Wang J, He H, Liu W, Ding Y, Lei Y, Li J, Wang Z, Zhang X, Wang Y, Cheng J, Liu Y, Shi Q, Yan L, Geng G, Hong C, Li M, Liu F, Zheng B, Cao J, Ding D, Gao J, Fu Q, Huo J, Liu B, Liu Z, Yang F, He K, Jiming Hao J (2019) Drivers of improved PM $_{2.5}$ air quality in China from 2013 to 2017. Proc Natl Acad Sci U S A 116:24463-24469. https://doi.org/10.1073/pnas.1907956116

Publisher's Note Springer Nature remains neutral with regard to jurisdictional claims in published maps and institutional affiliations.

\section{Affiliations}

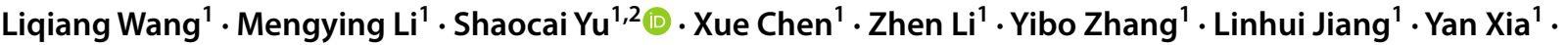 Jiali $\mathrm{Li}^{1} \cdot$ Weiping Liu ${ }^{1} \cdot$ Pengfei $\mathrm{Li}^{3} \cdot$ Eric Lichtfouse $^{4,5}$ - Daniel Rosenfeld ${ }^{6} \cdot$ John H. Seinfeld ${ }^{2}$}

Shaocai Yu

shaocaiyu@zju.edu.cn; shaoacaiy@caltech.edu

$\triangle$ Pengfei Li

lglpf@hebau.edu.cn

1 Key Laboratory of Environmental Remediation and Ecological Health, Ministry of Education; Research Center for Air Pollution and Health, College of Environmental and Resource Sciences, Zhejiang University, Hangzhou 310058, Zhejiang, People's Republic of China

2 Division of Chemistry and Chemical Engineering, California Institute of Technology, Pasadena, CA 91125, USA
3 College of Science and Technology, Hebei Agricultural University, Baoding 071000, Hebei, People's Republic of China

4 Aix-Marseille Univ, CNRS, Coll France, CNRS, INRA, IRD, CEREGE, Avenue Louis Philibert, 13100 Aix En Provence, France

5 State Key Laboratory of Multiphase Flow in Power Engineering, Xi'an Jiaotong University, Xi' an 710049, Shaanxi, People's Republic of China

6 Institute of Earth Sciences, The Hebrew University of Jerusalem, Jerusalem, Israel 